\title{
PERLINDUNGAN HUKUM TERHADAP PENGGUNA JASA ANGKUTAN SEWA UMUM DI PROVINSI BALI
}

\author{
Made Bayu Anggara, I Nyoman Sujana, Ni made puspautari ujianti \\ Fakultas Hukum Universitas Warmadewa, Denpasar-Bali, Indonesia
}

\begin{abstract}
Abstrak
Transportasi merupakan suatu bidang kegiatan yang sangat penting dalam memberi jasa pengankutan. Kebutuhan akan adanya transportasi (angkutan umum) semakin meningkat, daerah perkotaan semakin meluas dimana pola pergerakan sudah melingkupi antar wilayah Provinsi Bali. Angkutan orang dengan kendaraan bermotor tidak memiliki trayek diatur dengan Peraturan Menteri Perhubungan Nomor 108 Tahun 2017 tentang Penyelenggaraan angkutan orang dengan kendraan bermotor umum yang tidak dalam trayek. Penelitian ini bertujuan untuk menganalisis prosedur pelaksanaan penyelenggaraan angkutan sewa umperlinum di Provinsi Bali dan bagaimana perlindungan hukum terhadap pengguna jasa angkutan sewa umum di Provinsi Bali. Penelitian ini menggunakan metode penelitian hukum normatif yaitu dengan meneliti bahan hukum pustaka atau bahan primer dan data sekunder. Pendekatan yang digunakan adalah pendekatan perudang-undangan. Hasil penelitian menunjukkan bahwa pengaturan tentang perlindungan konsumen telah diatur dalam Undang-Undang Nomor 8 Tahun 1999 tentang perlindungan konsumen yang selanjutnya disebut UUPK. Perlindungan hukum bagi pengguna jasa angkutan sewa umum sudah mengacu pada Undang-Undang Nomor 8 Tahun 1999 mengenai perlindungan konsumen dimana sebagai pelaku usaha sekyogyanya memberikan pelayanan terbaik kepada para konsumen demi kenyamanan dan kebaikan bersama
\end{abstract}

Kata Kunci: Perlindungan Hukum; Jasa Angkutan; Sewa

\begin{abstract}
Transportation is a very important field of activity in providing transportation services. The need for transportation (public transportation) is increasing, urban areas are expanding where the pattern of movement has covered the inter-region of Bali Province. Transportation of people with motorized vehicles that do not have a route is regulated by Regulation of the Minister of Transportation Number 108 of 2017 concerning the Implementation of transportation of people with public motorized vehicles that are not on routes. This study aims to analyze the implementation procedures for the implementation of public rental transportation in Bali Province and how the legal protection for public rental transportation service users in Bali Province. This study uses normative legal research methods, namely by examining library legal materials or primary materials and secondary data. The approach used is a statutory approach. The results showed that the regulation on consumer protection has been regulated in Law Number 8 of 1999 concerning consumer protection, hereinafter referred to as UUPK. Legal protection for users of public rental transportation services has referred to Law Number 8 of 1999 concerning consumer protection whereas business actors should provide the best service to consumers for the sake of mutual comfort and good.
\end{abstract}

Keywords: Legal Protection; Transportation Services; Rent

\section{PENDAHULUAN}

Kegiatan pembangunan diseluruh bidang sangat membutuhkan jasa transportasi khususnya transportasi darat sebagai sarana untuk memindahkan orang atau barang. Jasa transportasi khususnya transportasi darat sangat dibutuhkan. peran sektor perhubungan memegang peranan yang sangat penting dalam kegiatan pembangunan (Tusmar \& Mora, 2015). Pembangunan dibidang infrastruktur menjadi kegiatan yang sangat membantu masyarakat sebagai akses meningkatkan perekonomian (Soares et al., 2015). Saat ini kelancaran lalu lintas dan juga angkutan jalan mengalami masalah yang serius dikarenakan kemacetan arus lalu lintas yang hampir terjadi diseluruh wilayah Provinsi Bali, sehingga menimbulkan kebisingan dan banyaknya gas CO2. Apabila hal ini dibiarkan terus menerus akan berpengaruh buruk terhadap pelaksanaan pembangunan daerah sebagai bagian dari pembangunan nasional.

Bali merupakan daerah tujuan wisata (DTW) sehingga kunjungan wisatawan baik domestik maupun mancanegara mengalami peningkatan setiap tahunnya maka dari itu kebutuhan akan 
transportasi (angkutan umum) semakin meningkat. Kedatangan wisatawan ke Bali terutama wilayah Kota Denpasar, Kabupaten Badung, dan Kabupaten Gianyar sangat memerlukan sarana dan prasarana pendukung seperti hotel, restoran, serta sarana/prasarana pendukung lainnya seperti transportasi dan komunikasi. Di samping sebagai daerah tujuan wisata, ketiga wilayah tersebut khususnya Kota Denpasar juga merupakan pusat berbagai kegiatan, seperti pusat pemerintahan Ibu Kota Provinsi Bali, dan Ibu Kota Denpasar, pusat perekonomian atau perdagangan, pusat pendidikan dan pusat kebudayaan. Kondisi seperti ini menyebabkan jumlah penduduk di Kota Denpasar menjadi semakin bertambah sehingga memerlukan tersedianya berbagai sarana dan prarasana untuk mendukung kegiatannya.

Sarana dan prasarana yang sangat dibutuhkan oleh wisatawan adalah sarana dan prasarana transportasi yang mendukung pergerakan penduduk, termasuk pula sarana pergerakan para wisatawan yang datang ke Bali. Transportasi merupakan suatu bidang kegiatan yang sangat penting dalam kehidupan manusia (Silondae et al., 2016). Kebutuhan akan adanya transportasi (angkutan umum) semakin meningkat, jasa angkutan umum di Propinsi Bali semakin meluas karena pola pergerakan sudah melingkupi antar wilayah Provinsi Bali. Semakin menyebarnya lokasi pemukiman dan aktivitas semakin besar, telah mengakibatkan pola pergerakan menjadi semakin kompleks, terjadi peningkatan pergerakan internal maupun eksternal yang melalui jalan-jalan utama di Kota Denpasar dan Kabupaten Badung. Perkembangan kebutuhan akan pergerakan (demand) yang pesat tidak mampu diimbangi oleh perkembangan sarana dan prasarana transportasi (supply).

Perkembangan kebutuhan pergerakan (demand) yang pesat tersebut tidak mampu diimbangi oleh perkembangan sarana dan prasarana transportasi (supply). Upaya penyeimbangan antara demand dan supply dapat dilakukan dengan pembangunan prasarana jalan. Khusus untuk mengantisipasi peningkatan jasa pelayanan angkutan bagi wisatawan, angkutan umum merupakan salah satu solusi yang tepat yang menggunakan kendaraan bermotor umum tidak dalam trayek seperti taksi, angkutan carter berupa bus, mini bus, angkutan pariwisata (baik berupa bus maupun minibus). Penelitian sebelumnya mengungkapkan bahwa Pengawasan terhadap jasa angkutan umum sangant penting dilkukan, akibat kurangnya pengawasan dari instansi terkait mengakibatkan ketidakpastian hukum dan dapat menimbulkan kerugian kepada pihak lain baik kerugian secara perdata maupun secara pidana (Hakim, 2019). Menurut Rusdiansyah et al., (2016) Perlindungan konsumen terhadap pengguna jasa angkutan kota tidak saja berpedoman pada peraturan yang telah ada namun juga dibantu dengan adanya kerjasama diantara pemerintah, masyarakat serta penyedia jasa angkutan kota yang nantinya diharapkan dapat terus membaik. Hak dasar konsumen dituangkan dalam aturan pemerintah yang berkaitan dengan perlindungan konsumen. Pentingnya keamanan dan keselamatan konsumen dalam penggunaan jasa angkutan sewa umum (Nasution, 1995).

Dari latar belakang di atas yang telah memberikan deskripsi bagaimana permasalahanpermasalahan yang terjadi, penelitian ini dilakukan bertujaun untuk mengetahui prosedur pelaksanaan penyelenggaraan angkutan sewa umperlinum di Provinsi Bali dan menjelaskan perlindungan hukum terhadap pengguna jasa angkutan sewa umum di Provinsi Bali.

\section{METODE PENELITIAN}

Penelitian ini menggunakan penelitian hukum normatif dan bahan hukumnya bersumber dari studi dokumen. Untuk mengidentifikasi kaidah dan norma-norma yang ada menggunakan bahan-bahan kepustakaan dan juga peraturan perundang-undangan yang berlaku. Adapun jenis bahan hukum dalam penelitian ini adalah bahan hukum primer merupakan sarana dari penelitian yang meliputi aturanaturan yang berkaitan dengan masalah yang diteliti sedangkan data Sekunder didapatkan dengan mempelajari dan memilah buku-buku yang relevan dengan penelitian ini (Library Research), yakni dengan membaca buku-buku, surat kabar dan juga sumber dari internet yang berkaitan jasa angkutan umum.

\section{HASIL DAN PEMBAHASAN}

\section{Prosedur Pelaksanaan Penyelenggaraan Angkutan Sewa Umperlinum di Provinsi Bali}

Angkutan umum memiliki peran yang penting dalam mendukung pembangunan serta membantu kelancaran kegiatan pariwisata. Aparat penegak hukum dalam hal ini pihak kepolisian dibidang laklantas sangat ditekankan dalam bekerja khususnya menciptakan keadaan kondusif, khususnya di Bali. Kepadatan penduduk sangat membutuhkan transportasi sehingga mereka mengadakan jasa angkutan 
umum dalam menunjang kegiatan masyarakat untuk memenuhi kebutuhan hidupnya. Angkutan umum yang diperlukan tidak saja untuk melayani pergerakan masyarakat antar kota dalam wilayah Provinsi Bali saja, tetapi juga angkutan umum untuk melayani pergerakan masyarakat antar kota di luar wilayah Provinsi Bali.

Sesuai UUD Tahun 1945 angkutan umum merupakan bagian dari Lalu Lintas dan angkutan Jalan memiliki peran yang sangat strategis untuk mendukung pembangunan untuk memperbaiki ekonomi masyarakat. Kepadatan kendaraan saat ini dengan rambu lalu lintas yang kurang diharapkan pihak yang terkait untuk membantu keseimbangan pengemudi angkutan umun dijalan sebagai salah satu cara untuk memperlancar perjalanan warga dalam rangka mendukung pembangunan ekonomi dan pengembangan wilayah.

Pelaku usaha perusahaan yang kegiatan penyelenggaraan pelayanan jasa angkutan sewa umum dan konsumen merupakan pengguna jasa sewa umum. Praktek pelayanan jasa ini pelaku usaha dan konsumen akan berhadapan sebagai dua pihak yang terlibat dalam kegiatan pelayanan jasa angkutan sewa umum yang masing-masing berkepentingan agar penyelenggaraan angkutan umum dapat berjalan dan saling menguntungakan dalam sektor perekonomian. Kelebihan sebagai konsumen disini banyak produk dan prodak yan ditawarkan membuat konsumen bingung dalam menentukan pilihannya. Peluang didapat oleh produsen yang membuat banyak produk ditambah dengan promosi yang diatur sedemikian rupa membuat ketidaksetaraan antara konsumen dan produsen. Konsumen seolah melupakan kepentingan pribadinya dengan banyaknya produk serta promosi yang ditawarkan produsen membuat ketidakseimbangan kedudukan konsumen dan produsen (Miru \& Yodo, 2004). Aktivitas tersebut membuat ketimpangan perjanjian antara kedua belah pihak, seharusnya konsumen menadapatkan kehendaknya bukan dibuat bingung oleh tingkah produsen yang membuat konsumen melupakan kepentingannya.

Dalam peraturan pemerintah tentang angkutan jalan dan lalu lintas terdapat beberapa komponen yang saling berkaitan meliputi transportasi, pengaturan lalu lintas dan pengendara sebagai objek dari peraturan itu sendiri. Secara etimologis, perlindungan diartikan sebagai tempat berlindung atau perbuatan melindungi. Pengaturan perlindungan konsumen dikonfirmasi konsumen sangatlah penting dalam halnya terjadinya kepastian hukum demi terciptanya keamanan bagi konsumen. Menurut Hadjon, (1993) ada dua perlindungan hukum yaitu perlindungan hukum bagi konsumen itu sendiri dan perlindungan atas orang lain. Maka dari itu pengusaha angkutan umum maupun masyarakat sebagai konsumen mendapat perlindungan hukum (Soekanto, 2007).

Angkutan umum sewa yang merupakan sub dari angkutan orang dengan kendaraan bermotor tidak dalam trayek, diatur dalam Peraturan Menteri Perhubungan Nomor 108 Tahun 2017. Membawa seseorang dengan menggunakan kendaraan bermotor tidak termasuk trayek karena merupakan aktivitas individu antar kelompok atau sebaliknya dimana aktivitas tersebut tidak memiliki batasan waktu untuk melakukannya karena masyarakat memiliki tujuan dan kesibukan yang berbeda. Peraturan Mentri berhubungan jasa angkutan umum yang membawa orang tidak termasuk trayek dilakukan oleh pemerintah, pemerintah daerah, perusahaan umum milik negara/daerah (BUMN/BUMD), koperasi atau swasta yang dalam kegiatannya wajib memenuhi ketentuan peraturan perundang-undangan yang berlaku.

\section{Perlindungan Hukum Terhadap Pengguna Jasa Angkutan Sewa Umum di Provinsi Bali.}

Pentingnya perlindungan terhadap konsumen sebagai upaya kepastian hukum terhadap konsumen (Budiartha, 2016). Pemerintah dewasa ini dalam menghadapi era globalisasi sudah membuat perpu yang berisikan peraturan yang mangatur kepastian hukum bagi konsumen. Perlindungan hukum kepada konsumen diperkuat dengan peraturan pemerintah dengan tujuan agar para konsumen mendapatkan perlakukuan yang sesuai seperti para pelaku usaha melakukan perbuatan sewenangwenang (Susanto, 2008).

Era globalisasi kian marak meracuni perkonomian masyarakat maka pemerintah membuat peraturan yang membentengi konsumen yaitu hukum perlindungan konsumen. Semakin hari semakin berkembang pesat kemajuan teknologi dan industri dengan perlindungan tersebut diharapkan masyarakat sedikit berhati - hati menggunakan hak kewajiban sebagi konsumen supaya tepat sasaran pola pikir produsen dan konsumen pada umumnya. Sebelum era globalisasi produsen menciptakan suatu produk dengan cara kuno atau belum semaju teknologi sekarang sedangkan warga di era globalisasi atau era berkembang membuat suatu produk dengan peralatan yang serba maju tetapi 
banyak diantaranya meluapakan kualitas barang itu sendiri, sehingga menciptakan ketimpangan keinginan antara barang yang dipasarkan dengan pembeli (mass consumer consumption). Seiring berjalannya waktu banyak diantara pembeli melupakan keinginannya membeli suatu prodak karena bahan dengan kualitas barang tidak sesuai.

Menurut Nasution, (1995) aturan yang mengaitkan perlindungan konsumen sudah dalam ruang lingkup asas-asas yang mengatur seseorang sebagai konsumen demi perlidungan terhadap dirinya sendiri. Konsumen sendiri sudah dalam aturan pemerintah yang mana dialah yang dapat menggunakan barang dan atau jasa yang sudah tersedia oleh penyedia keperluan. Orang sebagai penerima fasilitas dimaksud adalah pengguna jasa angkutan sewa umum. Dalam memanfaatkan jasa layanan angkutan sewa umum konsumen mengharapkan dapat menggunakan jasa seara aman selamat dan terjangkau, sebagai kualitas pelayanan yang dapat menciptakan kepuasan konsumen/ pengguna jasa.

Pengguna jasa angkutan sewa umum menikmat produk perusahaan penyelenggara layanan angkutan sewa umum untuk menunjang aktivitas yang dilakukannya dengan cara terlebih dahlu memesan agar pengusaha menyediakan layanan jasa angkutan yang akan dipergunakannya. Dari pemesanan tersebut terjadi hubungan antara pemesan dengan perusahaan sebagai penyedia jasa. Perjanjian ini dapat dilakukan secara lisan maupun tertulis yang mengatur langkah-langkah yang harus diambil oleh kedua belah pihak demi mendapatkan haknya dengan tujuan bahwa perjanjian itu menguntungkan pihak-pihak yang terkait.

Kendala yang dihadapi dalam penyelenggaraan kegiatan pelayanan jasa angkutan sewa umum, antara lain pengguna jasa angkutan sewa umum yang kurang menyadari arti penting perlindungan hukum terhadap dirinya sendiri dan persaingan tidak sehat diantara perusahaan dalam menentukan besaran sewa dan seringkali perusahaan memberikan komisi kepada orang yang mewakili masyarakat dalam pengurusan pemesanan kendaraan dari suatu perusahaan. Untuk mengatasi kendala tersebut upaya yang dapat dilakukan adalah dengan turut campurnya Pemerintah dan Pemerintah Daerah.

\section{SIMPULAN DAN SARAN}

\section{Simpulan}

Berdasarkan pembahasann dan analisis data dapat disimpulkan bahwa penyelenggaraan angkutan sewa umum dilakukan oleh perusahaan swasta (PT, CV) dan koperasi yang telah memenuhi persyaratan sesuai ketentuan peraturan perundang-undangan yang berlaku dan penyelenggaraannya yang sudah mengacu pada Undang-Undang Nomor 22 Tahun 2009 tentang lalu lintas dan angkutan jalan serta peraturan mentri yang mengatur setiap perilaku pengguna jalan raya agar tetap mengikuti ketentuan yang berlaku dijalan raya demi terciptanya keadaan kondusif dan mengurangi angka kecelakaan dijalan, yang kedua Perlindungan hukum bagi pengguna jasa angkutan sewa umum sudah mengacu pada Undang-Undang Nomor 8 Tahun 1999 mengenai Perlindungan Konsumen dimana sebagai pelaku usaha sekyogyanya memberikan pelayanan terbaik kepada para konsumen demi kenyamanan dan kebaikan bersama. Dalam pasal 24 angkutan sewa umum termasuk dalam kategori atau jenis angkutan umum dengan kendaraan bermotor tidak dalam trayek yang termasuk dalam kegiatan simbiosis mutualisme dimana satu pihak memanfaatkan kepunyaannya sebagai penyedia jasa angkutan kendaraan dan satu sisinya lagi sebagai pihak yang menggunakan kendaraan tersebut dengan perjanjian yang telah disepakati dengan jangka waktu tertentu.

\section{Saran}

Dari hasil penlitian, peneliti memberi saran yaitu kepada pihak kepolisian di bidang satlantas untuk mengawasi kegiatan pengangkutan sewa umum sehingga tidak menimbulkan kemacetan, selanjutnya agar konsumen yang notabene sebagai pengguna jasa angkutan tidak diperlakukan sewenang-wenang , diharapkan pemerintah membuat undang-undan terhadap perlindungan konsumen

\section{DAFTAR PUSTAKA}

Budiartha, I. N. P. (2016). Hukum Outsorcing, Konsep Alih Daya, Bentuk Perlindungan, dan Kepastian Hukum. Setara Press.

Hadjon, P. M. (1993). Penghantar Hukum Administrasi. University Press.

Hakim, R. A. (2019). Perlindungan Hukum oleh Perusahaan Aplikasi terhadap Pemilik Kendaraan Angkutan Sewa Khusus. Adliya, 13(1), 58-72.

Miru, A., \& Yodo, S. (2004). Hukum Perlindungan Konsumen. Rajawali Pers. 
Nasution, A. Z. (1995). Konsumen dan Hukum. Pustaka Sinar Harapan.

Rusdiansyah, M. F., Njatrijani, R., \& Mahmudah, S. (2016). Transportasi Angkutan Darat (Angkot) di Semarang Ditinjau Dari Undang-Undang Nomor 8 Tahun 1999 tentang Perlindungan Konsumen. 5(4), 1-15.

Silondae, S., Muthalib, H. A. A., \& Ernawati. (2016). Keterkaitan Jalur Transportasi dan Interaksi Ekonomi Kabupaten Konawe Utara dengan Kabupaten/Kota Sekitarnya. Jurnal Progres Ekonomi Pembangunan, 1(1), 49-64.

Soares, A., Nurpratiwi, R., \& M.Makmur. (2015). Peranan Pemerintah Daerah Dalam Perencanaan Pembangunan Daerah. Jurnal Ilmu Sosial Dan Ilmu Politik, 4(2), 231-236.

Soekanto, S. (2007). Faktor-Faktor yang Mempengaruhi Penegakan Hukum. PT Raja Grafindo Persada.

Susanto, H. (2008). Hak-hak Konsumen Jika Dirugikan. Visimedia.

Tusmar, T., \& Mora, M. (2015). Perkembangan Perekonomian Wilayah dan Kargo Udara: Korelasi atau Kausalitas. Jurnal Perhubungan Udara, Warta Ardhia, 41(1), 39-48. 